\title{
Accuracy and Precision of Polysemous Judgment Terms in Legal Translation: A Corpus-based Method and Discussion
}

\author{
Yanzhen Lan \\ Qingdao University of Science and Technology, Qingdao, China
}

\begin{abstract}
The primary goals of this paper are on one hand to emphasize the accuracy and precision of legal translation, on the other hand to describe the superiority of a corpus-based method and discussion in legal translation. It is beneficial to both practice of legal translation and study of corpus linguistics further to ensure the accuracy and precision of translation of polysemous judgment terms in legal translation.
\end{abstract}

Index Terms - accuracy, precision, polysemy, legal translation, corpus

\section{INTRODUCTION}

Legal translation is the translation of articles within the field of law. And far from being separate, the law and life form an indivisible whole. By the increasing process of globalization and the intercultural study over the past decades, the legal translation has been playing a significant role in the life. Especially, we need to use the experience of other countries for reference in the perfection of the legal mechanism, the legal translation in Chinese is therefore steadily ceaselessly paid attention to.

As law is closely related with many elements, such as culture and language, the legal translation needs to be considered in more aspects. If the accuracy and precision of legal translation is not absolutely assured, that means the misreading of legal passages, for example, a text in a contract, could lead to loss of wealth and even lawsuits. In the Chinese translation of legal texts, many factors should be taken into account. One of the impact factors, which could impair the correct quality of the to be translated legal texts, are polysemous judgment terms in legal translation.

It could be summed up that a polyseme is a word or phrase with two or more meanings. And there are often links between these several meanings. The polysemy is a very common and complicated linguistic phenomenon in Chinese, which also influences the quality of legal translation.

Considering the seriousness in legal texts and the frequent polysemy in Chinese, it is necessary to attach importance to accuracy of Chinese- English translation of polysemous judgment terms. As to the problem of how to deal properly with all kinds of complicated items in the Chinese- English legal translation, the study on corpora provides of good chances to ensure and improve the quality of legal translation.

\section{PRinciples of Legal TRanslation}

Legal translation is a kind of double operation of legal transfer and language transfer (Sarcevic 12). According to Li Kexing, there are six practical principles of legal translation: Accuracy and Precision; Consistency and Identity; Clarity and Concision; Professionalism; Standardized Language; Team Work (Li 46). Accuracy and precision are regarded as the fundamental principle. Chinese is simple, flexible and poetic yet fuzzy, which easily leads to ambiguity in legal texts. The academic world has made a lot of criticism about the non-logic, fuzzy problems in the Criminal Law of the People's Republic of China in 1979.

Mellinkoff (1963) argued that for legal and official purposes, it is usually necessary to apply documents serving as or based on evidence and other official documentation in the official language(s) of a jurisdiction. In some countries, translators are required to swear an oath to attest that translations of such documents are the legal equivalents of the source texts. Newmark (1988), Sarcevic (1997) pointed that when translating a legal text, the translator should keep the words "Accuracy and Precision" in mind. Prioritizing culture-fit as a key factor in the legal system of the source text, which is for short as ST, is an obvious reflection in the legal language. Similarly, the readers of the target text, which is for short as TT, have on the whole thoroughly acquainted knowledge of the other legal system and its language through study or experience. One of the conspicuous features for most forms of legal writing, and contracts in particular, is to establish clearly defined rights and duties for certain individuals, of which is therefore absolutely necessary to ensure accurate correspondence in the source text and in the translation.

Accuracy is the soul of legal words, but different language has its own characteristics, there are diversities in terms of accuracy. For example, since the accuracy of the French is better than that of other languages, in some international conventions the texts in French would prevail, if there is ambiguity in different language texts. Chinese has the 
advantages of simple, flexible, and poetic characteristics, whose deficiency is nevertheless its fuzziness, because it has to do with the Chinese traditional way of thinking. The Chinese ambiguity is easy to cause the inaccuracy of legal texts. One of the typical examples is, the fuzzy phenomenon in our 1979 criminal law had repeatedly come under strong criticism from the academia. On the other hand, compared to the wide range of lexical meanings in Chinese, the word meaning in English is usually more specific. Therefore, it often appears that the same Chinese words need to use different English words to express. For example, the word “责任” in the legal system of the source text Chinese, has many possible associated translations in the target language system English, such as duty, liability, responsibility etc.

\section{Polysemous Judgment TeRms In CHINESE}

Many foreign and domestic scholars, such as Klein \& Murphy (2001), Hjort-Pedersen \& Faber (2001), Rodd, Gaskell \& Marslen-Wilson (2002), Koskela (2005), Beretta, Fiorentino \& Poeppel (2005), Hino, Pexman \& Lupker (2006), Li (2007), Klepousniotou \& Baum (2007) have been discussing the concrete contents of polysemy for years. Fillmore and Atkins (2000) argued that the definition stipulates three elements: (i) although polysemous words have different meanings, they come mostly from a same central origin. (ii) A framework is formed between these diverse meanings. (iii) The internal understanding (or understanding the "inner" one) is conducive to the external understanding (or understanding of the "outer" one). For Hebdige (1979), in the frame of polysemous word each article has the potential to produce large amounts of meaning. According to Middleton (1990/2002), no polysemous word is almost impossible.

In the following, there are some examples from Collins English Dictionary. At first, we could take the word "Man" as an example.

Example 1. Are you a gambling man, Mr. Berth?

Example 2. ... as the Stock-port man collected his winnings...

These two examples are refereed to a group or kind of people who have similar features.

Example 3. She had not expected the young man to reappear before yesterday...

In this sentence, the man refers to an adult male human being.

Example 4.... if they see your man cuddle you in the bathroom or kitchen.

Here has the word "man" specific meaning: some people refer to a woman's husband, lover, or boyfriend as her man.

Actually, example 1or 2 contains 3 , and 3 contains 4 .

There is also a set of Chinese judgment terms that are more polysemous than their English counterparts within the legal domain. Therefore, there is a lack of one-to-one correspondence of legal terms between English and Chinese.

Here we could take the word “裁决” as an example. We have usually "sentence” and "verdict” as choices. The word "sentence" usually refers to the punishment that the suspect receives in a law court after he or she was convicted. The word "verdict" usually refers to the final judgment given by a judge or jury at the end of a trial. Therefore, in the first example sentence from Collins: Cobuild English Dictionary, the word "Sentence" is chosen as the translation word:

Example 1. The person carry a maximum sentence of 15 years.

It means that the person receives a punishment of 15 years after he or she was convicted.

In Example 2 (also from Collins: Cobuild English Dictionary), the word "Verdict" is chosen as the translation word:

The jury returned a unanimous guilty verdict. It means that the jury had a final decision.

Despite of their semantic relatedness (because both are related to the results of a trial), the "verdict" and the "sentence" are sufficiently distinguished. However, when expressed in, or more often translated into, Chinese, the accuracy is somehow weakened.

\section{CORPUS-BASED EXPLORATION AND METHOD}

A corpus is a collection of authentic texts and documents prepared for computer processing (Hunston 2).Nowadays corpora have a verity of uses, here are some summarized: For language learning, corpora can be explored by students themselves to "observe nuances of usage and to make comparisons between languages" (Hunston 13). For language teaching, corpora can provide information about "how a language works that may not be accessible to native speaker intuition" (Hunston 13). Many scholars, such as Connor \& Upton(2009), Thompson \& Hunston(2010), argued that translators could take advantages of corpora to make their translations more accurate and native. What's more, corpora are regarded as perfect platforms of translation verification. Besides, corpora are significant resources for dictionary, especially frequency-dictionary, and for research of linguistic, stylistic and culture.

The type of corpora depends on the purpose of the corpus. Here are some common ones: Specialized corpus, General corpus, Comparable corpus, Parallel corpus, Learner corpus, Pedagogic corpus, Historical or diachronic corpus, Monitor corpus (Hunston 16). Specialized (legal) and parallel corpora are used in the study of this paper.

We take “责任”“判决”these two typical words as examples, which are used in high frequency in the legal context and translation. We searched the Chinese word in the corpus and took out respectively two or three examples for every translation possibility from the searching results. All of the following items and examples are taken from the "Parallel Corpus of China's Legal Documents (PCCLD)" (http://corpus.usx.edu.cn/lawcorpus1/index.asp, http://corpus.usx.edu.cn/lawcorpus3/index.asp, http://corpus.usx.edu.cn/lawcorpus2/index.asp) and the sources and 
reference are cited in brackets after the examples. These data are moderate in quantity and reasonable in distribution, and they could reflect the actual use of a language item.

A. The Word in Chinese “责任”

The corpus retrieval results show that the corresponding English translation has the following possibilities:

(1) duty

Example a) 業主的責任 (from HK0303C0229)

Translation: DUTIES OF PROPRIETORS (from HK0303C0229)

Example b) 司法常務官有責任將結果通知審裁處 (from HK0004C0418)

Translation: Duty of Registrar to notify tribunal of result (from HK0004C0418)

Example c) 免除破產人在第(1)款下的責任 (from HK0005C0889)

Translation: Release the bankrupt from his duty under subsection (1) (from HK0005C0889)

Analysis: The results from the corpus indicate that the word "duty" usually refers to a task that someone has to perform for legal reasons (example a and b), or the force that someone is bound to do out of his or her obligations (example c).

(2) responsibility

Example a) ......但該管制人員須負個人責任。(from HK0001C0852)

Translation: The controlling officer may, on his personal responsibility, ... (from HK0001C0852)

Example b) ......規定律師無須因疏忽而負上法律責任，或免除他負上如非有該等條文則作為律師須負上的任 何責任，均屬無效。”(from HK0708C0325)

Translation: ... or that he shall be relieved from any responsibility to which he would otherwise be subject as a solicitor, shall be void. (from HK0708C0325)

Example c) 保管人: 需要对于客户证券负法律责任的金融机构。（from 财经双语词典 C0368）

Translation: Custodian: A financial institution that has the legal responsibility for a customer's securities. (from 财经 双语词典E0368)

Analysis: From the results of corpus, we could find that the word "responsibility" is used in highest frequency, which refers to duties because of someone's task or position (example a and b), or the action that will protect someone's interests(example c).

(3) liability

Example a) 該人須承擔的法律責任及義務，與破產人在破產呈請提出當日根據該財產的租契而須承擔者相 同。(from HK0006C0341)

Translation: ... subject to the same liabilities and obligations as the bankrupt was subject to under the lease in respect of the property at the date when the bankruptcy petition was filed; or... (from HK0006C0341)

Example b) 截至 1990 年 3 月 31 日學生貸款基金就財務委員會核准的計劃而從學生貸款基金批出貸款予學生 所須承擔的一切法律責任。(from HK0002C0040)

Translation: all the liabilities of the Student Loan Fund in respect of schemes approved by the Finance Committee as at 31 March 1990 for the purpose of granting loans to students out of the Student Loan Fund. (from HK0002C0040)

Analysis: The word "liability" generally refers to reasons which cause problems or embarrassment (example a) or a financial obligation(example b).

Conclusion: This Chinese word has been mostly identified as the translation equivalent for "duty, liability, responsibility" in the bilingual corpus of court judgments. It is concluded that "duty" focuses on somebody; "responsibility" is more often used to express the word "责任" and in general together with a definite description like personal, court, retiree and so on; "liability" is generally used in some specific fields. In this way, we could improve the accuracy of terms when we process some Chinese-English legal translations.

B. The Word in Chinese “判决”（或“裁决”“决定”“裁定”）

The corpus retrieval results show that the corresponding English translation has the following possibilities:

(1) verdict

Example a) 陪审团作出“无罪”判决。

Translation: The verdict from the jury is NOT GUILTY.

Example b) 第二百零九条第一审人民法院判决被告人无罪、免除刑事处罚的, 如果被告人在押, 在宣判后应 当立即释放。（from 刑事诉讼法c579）

Translation: Article 209 If a defendant in custody is given the verdict of not guilty or exempted from criminal punishment by a People's Court of first instance, ... (from 刑事诉公法e579)

Analysis: As we have discussed, the word "verdict" usually refers to the final judgment given by a judge or jury at the end of a trial. The retrieval results also clearly verified the statements.

(2) judgment 
Example a) 第十二条法官对与当事人实体权利和诉讼权利有关的措施和判决应当依法说明理由，避免主观、 片面地作出结论或者采取措施。( from 法官道德准则 CO20)

Translation: Article 12. A judge should specify the reasons for the measures and judgment relating to the substantial rights and litigating right of the parties.... (from 法官道德准则 E020)

Example b) 第三十九条 ........ 协议不成时, 由人民法院根据财产的具体情况, 照顾子女和女方权益的原则判 决。(from 婚姻法C081)

Translation: Article 39 ... In cases where an agreement cannot be reached, the people's court shall make a judgment in consideration of the actual circumstance of the property and on the principle of caring for the rights and interests of the wife and the child or children. (from 婚姻法E081)

Analysis: The examples indicate that the word "judgment" is usually a decision made by a judge or by a court of law (example a and b). In this sense, the word "judgment" has similar use and meaning with "verdict".

(3) decision

Example a) 第七十五条 金融监督管理部门自收到设立保险公司的正式申请文件之日起六个月内，应当作出 批准或者不批准的决定。(from 保险法 1778 )

Translation: Article 75 The financial supervision and regulation department shall make a decision approving or disapproving the application, ... (from 保险法e178)

Example b) 复议期间，原处罚决定照常执行。（from 价格管理条例 C103）

Translation: The original penalty decision shall be implemented as usual during the period of reconsideration. (from 价格管理条例 C103)

Analysis: The word “decision” has been rendered as “决定” in Chinese, chosen what should be done or which is the best possibility of various actions, among many possibilities.

(4) order

Example a) 拒不履行人民法院已经发生法律效力的判决、裁定的。(from 民事诉讼法 C305)

Translation: ...refusing to carry out legally effective judgments or orders of the people's court. (from 民事诉讼法 C305)

Example b) 海事法院对确权诉讼作出的判决、裁定具有法律效力, 当事人不得提起上诉。（from 海诉程序法 C292)

Translation: The judgment and order made by the maritime court on an action for affirming rights shall be legally effective, the parties shall not file an appeal. (from 海诉程序法 C292)

Analysis: The word "order" is usually used with the word "judgment" as the translation for the word “裁定”.

Conclusion: We could conclude that the word "verdict" and "judgment" are preferred to be translated into “判决” “裁决”. The word "verdict" refers usually to a decision of a legal group like the jury or the board; the word "judgment" is more frequently applied and ordinarily combined with someone who gives out the legal decision like a judge or a court. The word “decision" has been in general rendered as “决定” in Chinese and the word “order" is usually applied for the translation of the word “裁定”.

\section{CONCLUSION}

As the foundation of legal translation, accuracy and precision are the dominant factors to decide the quality of legal translations. However, not all translators are so competent to translate legal documents and texts precisely, which are resulted from different knowledge and culture background. The above mentioned two examples are taken to discuss, how can translators correctly use the corpus to choose the accurate word in the translation process. We could get the impression that through the correct use of the retrieval results from the corpus, the accuracy and precision of polysemous judgment terms in legal translation could be verified and improved. It could be also foreseen that the corpus is exerting more influences on translation in legal and other fields.

\section{REFERENCES}

[1] Beretta, A., Fiorentino, R., \& Poeppel, D. (2005). The effects of homonymy and polysemy on lexical access: AN MEG study. Cognitive Brain Research 24, 57-65.

[2] Collins: Cobuild English Dictionary. http://www.collinsdictionary.com/dictionary/english (accessed 16/6/2016).

[3] Connor, Ulla \& Upton, T.A. (2009). Applied Corpus Linguistics: A Multidimensional Perspective. Beijing: World Book Publishing Company.

[4] Fillmore, C.J\& Atkins, B.T.S. (2000). Describing polysemy: The case of "crawl". In Ravin, Y; Leacock, C. Polysemy: Theoretical and computational approaches. Oxford: Oxford University Press, 91-110.

[5] Hebdige, D. (1979). Subculture: The Meaning of Style. New York: Metheun.

[6] Hino, Y., Kusunose, Y., \& Lupker, S.J. (2010). The relatedness-of-meaning effect for ambiguous words in lexical-decision tasks: When does relatedness matter? Canadian Journal of Experimental Psychology 64, 180-196.

[7] Hino, Y., Pexman, P.M., \& Lupker, S.J. (2006). Ambiguity and relatedness effects in semantic tasks: Are they due to semantic coding? Journal of Memory and Language 55, 247-273. 
[8] Hjort-Pedersen, Mett \& Faber, Dorrit. (2001). Lexical ambiguity and legal translation: a discussion. Multilingua 20, 4, 379-392.

[9] Hunston, Susan. (2002). Corpora in Applied Linguistics. London: Cambridge UP.

[10] Jennifer, Rodd, M, Gareth Gaskell \& William, Marslen-Wilson. (2002). Making Sense of Semantic Ambiguity: Semantic Competition in Lexical Access. Journal of Memory and Language 46, 245-266.

[11] Jennifer, Rodd, M, Gareth Gaskell \& William, Marslen-Wilson. (2004). Modelling the effects of semantic ambiguity in word recognition. Cognitive Science 28, 89-104.

[12] Klein, D.E., \& Murphy, G.L. (2001). The representation of polysemous words. Journal of Memory and Language 45, $259-282$.

[13] Klein, D.E., \& Murphy, G.L. (2002). Paper has been my ruin: Conceptual relations of polysemous senses. Journal of Memory and Language 47, 548-570.

[14] Klepousniotou, E., \& Baum, S.R. (2007). Disambiguating the ambiguity advantage effect in word recognition: An advantage for polysemous but not homonymous words. Journal of Neurolinguistics 20, 1-24.

[15] Koskela, Anu. (2005). On the distinction between metonymy and vertical polysemy in encyclopaedic semantics. http://sro.sussex.ac.uk/24023/ (accessed 16/1/2016).

[16] Li, Kexing. (2007). Legal Translation: A Theoretical and Practical Approach. Beijing: Peking University Press.

[17] Mellinkoff, David. (1963). The Language of the Law. Boston: Little Brown.

[18] Newmark, Peter. (1988). Approaches to Translation. London: Cambridge UP.

[19] Parallel Corpus of China's Legal Documents. (PCCLD). http://corpus.usx.edu.cn/lawcorpus1/index.asp, http://corpus.usx.edu.cn/lawcorpus3/index.asp, http://corpus.usx.edu.cn/lawcorpus2/index.asp (accessed 16/3/2016).

[20] Sarcevic, Susan. (1997). New Approach to Legal Translation. The Hague: Kluwer Law International.

[21] Smith, J. (1999). Criminal Law. London: Butterworths.

[22] Thompson, Geoff \& Hunston, Susan. (2010). System and Corpus: Exploring Connections. Beijing: World Book Publishing Company.

Yanzhen Lan, Female, Lecturer in Qingdao University of Science and Technology. Her research fields are literature, foreign language teaching and intercultural communication. 